\title{
INFORMATION MAMAGEMENT ISSUES IN THE DIGITAL ERA
}

\author{
Dr. Priyanki R. Vyas \\ \& \\ Mr. Mahendra B. Patel
}

\begin{abstract}
$\underline{\text { Abstract }}$
Information and communication technology is a collective mixing of digital and electronic media for creation, acquisition and dissemination of information and knowledge. ICT has also given birth to new forms, formats of recording information and tools and techniques of handling information. With advancement in technologies with time, internet has been modifying from "browse and surf" environment into a enormous knowledge exchange. This paper studies the emergence of web-based ICT, globalization of networks and internet which have greatly affected the library professionals and profession. This provides new opportunities and challenges for library professionals.
\end{abstract}

\section{Introduction}

Now a day's importance of information and knowledge is the driving force of development. Information and communication technology plays vital role for this development. Due to ICT, society is developing almost in all disciplines. Growth and development in information and knowledge is the one of this development part. Thus information management is a part of communication and human resources management.

\section{Conversion}

In earlier time, Librarian was regarded as a curator of library material. But with the passing of time, new development in ICT technology, open the new ways in information and 
knowledge handling, storage and exchange. Thus library transfer from a mere store house of documents to a dynamic power house of knowledge and information. This has conducted an innovative change in the ways libraries adopt and function. Today almost every in the society involve in information and knowledge generation and most of them prefers the electronics formats because it is easier and economic to crate, preserve, handle and disseminate at a faster speed than print formats.

Digital technology, high speed internet, computers etc have become an integral part of modern library. The appearance of web-based ICT, globalization of network and internet, all have extremely affected the library professional and profession and has provided new opportunities and challenges for library professionals.

\section{ICT and its Problems Areas}

ICT is a collective mixture of digital and electronic media for creation, acquisition and dissemination of knowledge. ICT has restructure the functioning of libraries which near to were simple storehouse of printed books and reading materials. Development in ICT, has also given birth to new formats and forms of reading information and new tools and techniques of handling information. With the adoption of ICT into library system the under problem areas are notable:

1. Accessibility and affordability

2. Trained manpower storage

3. Librarian's fear of technology

4. Lack of motivation

5. Disinterest of management

6. Lack of budget

7. Maintenance of ICT resources

8. Plagiarism issues

9. Lack of Funding

10. Lack of space

11. Un-availability of computers

12. Un-availability/slow internet connection

13. Un-availability of related soft ware's

14. Un-availability of back up services i.e. electricity/generator 
15. Staff's attitude towards ICT adoptability

16. Lack of interest by library users

17. Lack of co-operation within libraries

\section{ICT and its Challenges}

ICT has allow instant access to vast information in many formats at anywhere in any time to any users. But some challenges hoisted by ICT in the library are:

1. Libraries and librarians role are change

2. Copyright management

3. How to preserve digital information resources?

4. Ways of access information and communication with users are constantly change

5. Day to day change in technology

6. Aggressive growth in demand for global information

7. Generation of vast information

8. More technology dependence

\section{Information Management Issues}

Retrieval of information from any sources is very useful to satisfy the users' demands. There are delegate records which give enough information to identify information demand of users. The basic retrieval tools are bibliographies, indexes, cataloging, registers, directories, search engines etc. ICT has change information organization way, significant issues regarding information management in digital era are:

a. ICT tools application in library automation

b. Better ingenious ways for measuring information productivity

c. Proper access to information resources

d. Increase importance on information literacy and user education

e. Increase users responsibility

f. Co-ordination, control and decentralization on information

g. Information reliability, authenticity and validity

h. Trained library professionals and employers

i. Participation of IT professionals in information management 


\section{Search for Excellence}

Information management include user orientation for how to retrieval information from print and others various sources. Users have to retain well aware of the advances achieved in information management technologies. Information management also includes library automation, skilled human resources and feeling of library environment. In a traditional library conventional documents like printed books, audio, video materials and microfilms etc cannot be accessed by several users concurrently. With the advance growth of internet, it is now possible to access the required material in any libraries, any time, any place, and any users at a time.

With the help of advance technologies, continuous research activity huge generation of information and knowledge in the society. Libraries need to develop their resources, access and sharing strategies for satisfied users' multidisciplinary demand. Librarians have to aware about methods such as data mining, content management, semantic webs are some of the recent developments in information management.

\section{ICT Based Library Services}

ICT based library services include:

1. Speedy and easy access to information from any sources to any users at any time and any place.

2. Provide remote access to information.

3. Access to unlimited information from varied access points.

4. Increase information flexibility to be used by any user, according to individual requirements.

5. Smooth arrangement and integrate of data from different sources.

\section{Digital Concept and Information Management}

Information and knowledge are two important and key factors in all development activities. The flow of these has to be efficient to be made available for use and exploitation. Digital concept offers important, remarkable and unique improvement and value addition to library services. Fast and improved information retrieval and increase document delivery 
capacity are the widely stroking strength of digital libraries. With the help of digital concept, work places are organized such a way that the required documents are retrieve faster without more work process. Librarians are involved in a counting search for excellence in organizing and classifying information sources. Information in digital library is electronically stored and access simultaneously by multiple users, ensuring continuous availability of documents.

Information management includes information collection, organization, preservation and dissemination of information for growth and development of society. Now a day's social media change the way of information management and dissemination. We are in beginning stage of information revaluation, with the development in ICT technologies in going days, many more changes are seeing, so librarians need to know how to utilize the current technology, how to designing information storage and retrieval systems, how to develop protocol for collecting, organizing, classifying and interpreting information. Librarians have to function as information brokers between content providers and remote users.

\section{User Community in Net Generation}

Net Generation has grown up with information technology. The aptitudes, attitudes, expectations, and learning styles of net generation students reflect the environment in which they were raised-one that is decidedly different from that which existed when faculty and administrators were growing up. This generation students and users are utterly different in character from previous generations. Internet has become crucial requirement for colleges and universities students. Today's students are different; they're much more techno savvy in their lives, but they still like personal contact. They access information with a few clicks. They prefer to look up for flood lined information flow. Wikipedia is proffered over other traditional encyclopedias. But authenticity of information found on the web is major issue. Present generation users expect access to most recent information, updated information resources and latest ICT facilities. Anyone interested in providing the best education possible can use this as a first step in reflecting on what the net generation means for their campus. 
Towards Excellence: An Indexed, Refereed \& Peer Reviewed Journal of Higher Education / Mr.

Mahendra Patel \& Dr. Priyanki Vyas / Page 106-111

\section{Conclusion}

The growth and develop in digital information resources impose new roles and relationships for libraries and librarians. The earlier role of providing information has now changed to providing access to information. The users and readers of digital age are information seekers and information consolidators. The librarians' role is information service providers. In order to meet demand of the diversified user community, libraries in digital environment have to develop ways to manage access to materials in e-format and also effectively share them among the users community. The new digital ICT is not a single technology but a combination of hardware and software, multimedia and delivery systems. As ICT advanced, the costs of hardware and software decrease and the digital option became more attractive. When it was realized that sharing costs would benefit the stakeholders, resource sharing of digital resources gained power. Internet has transformed from "browse and surf" environ into a mammoth "knowledge exchange" environ. Internet can be a vehicle for inexpensive easy mass distribution of products and services. There are limitations as well, such as security and privacy issues, hackers, worms, viruses and Trojan horses and plagiarism. The real questions are how do we stay connected? How do we share our knowledge? How do we function anytime, anywhere, no matter what?

\section{$\underline{\text { References }}$}

1. Kadam, Urmila R. and Khot, Namita B. (2012). Knowledge Management and Organization in the Libraries: An Overview. International Conference on Knowledge Management and Organization in the Digital Era (ICKMODE2012), Tumkur, 168-171. 2. Singh, Praveen (2008). Library Automation in Modern Age, New Delhi: Alfa Publication. 3. Stanley, M.K.(2010). The Changing Reference Culture: An Agenda for Digital Reference Service. ICSSR/OUAT National Seminar on Dynamics of e-resources and usage trends in digital era, Bhubaneswar, (10-11 254-263. 4. Uma, Rajan(2012). Knowledge Management and the Libraries. International Conference on Knowledge Management and Organization in the Digital Era (ICKMODE2012), Tumkur, 64-67.

Patel Mahendra B. Assistant Librarian K.S.V, Gandhinagar Ph.D Scholar mahinmegha@gmail.com
Dr. Priyanki R. Vyas

Associate Professor

\& Department of Library and Information science

Dr. Babasaheb Ambedkar Open University priyankivyas@gmail.com 